\title{
IMPACT OF DEPTH OF CUT ON CHIP FORMATION IN AZ91HP MAGNESIUM ALLOY MILLING WITH TOOLS OF VARYING CUTTING EDGE GEOMETRY
}

\author{
Olga Gziut ${ }^{1}$, Józef Kuczmaszewski², Ireneusz Zagórski² \\ 1 Student of Mechanical Engineering Faculty, Lublin University of Technology, 36 Nadbystrzycka Str., 20-618 \\ Lublin, Poland \\ 2 Department of Production Engineering, Mechanical Engineering Faculty, Lublin University of Technology, 36 \\ Nadbystrzycka Str., 20-618 Lublin, Poland, e-mail: j.kuczmaszewski@pollub.pl; i.zagorski@pollub.pl
}

Received: 2015.04.01

Accepted: 2015.05.08

Published: 2015.06.01

\begin{abstract}
Safety of Mg milling processes can be expressed by means of the form and the number of fractions of chips formed during milling. This paper presents the state of the art of magnesium alloys milling technology in the aspect of chip fragmentation. Furthermore, the impact of the depth of cut $a_{p}$ and the rake angle $\gamma$ on the number of chip fractions was analysed in the study. These were conducted on AZ91HP magnesium cast alloy and milling was performed with carbide tools of varying rake angle values $\left(\gamma=5^{\circ}\right.$ and $\left.\gamma=30^{\circ}\right)$. It was observed that less intense chip fragmentation occurs with decreasing depth of cut $a_{p}$. The number of chip fractions was lower at the tool rake angle of $\gamma=30^{\circ}$. The test results were formulated as technological recommendations according to the number of generated chip fractions.
\end{abstract}

Keywords: high-speed dry milling, magnesium alloys, machinability, magnesium chips, end-mill geometry.

\section{INTRODUCTION}

The industry applications set a number of requirements to any technology in use, and increasing manufacturing efficiency is among the most vital. In milling this could not be achieved without advances in technological parameters of machining (predominantly $v_{c}$ and $f_{z}$ ). Subtractive machining, including milling, bases heavily on the changes of these parameters. Although the depth of cut $a_{p}$ is adjusted for particular applications, its impact is frequently disregarded. In magnesium alloy milling it is of utmost importance to limit the formation of dust fraction, which is highly susceptible to ignition. It is known that there is a correlation between the number of chip fractions and the increase or decrease of certain technological parameters and other analysed factors. Therefore, it appears necessary to investigate into the most efficient solutions, in terms of both effectiveness and safety of the realised process.

Chip formation is an inseparable aspect of milling process. However, the chips formed in magne- sium alloy machining might pose a serious threat to the health of milling machine operators, what is more, the machine life can be shortened, as fine chips can lead to incorrect work of machine elements, such as: bearings, cables or guideways. The danger of uninitiated chip and dust ignition is a further reason behind the development of milling technology towards chip formation monitoring during milling.

Modern machining technologies are characterised by increasing process efficiency without sacrificing the quality of surface. This could be referred to as the optimal process performance. Modern technologies of manufacturing include: HSM machining (offering high efficiency and quality, machined surface roughness $R a \leq 1 \mu \mathrm{m}$ ) [17], HPM, HPC (offering optimal use of spindle performance with simultaneous high material removal rate, technique resembling roughing or shaping machining) or HSC (finishing method) [7, 14, 15]. The application of these methods of machining makes the process much more time-efficient. In addition, milling (high-speed in particular) typically serves as a roughing and finishing method $[7,17]$. 
Another key factor describing safety of the realised machining process is temperature in the cutting zone $[3,11]$, which has a direct impact on the number of chip fractions formed in milling process [20]. There is a certain correlation between chip fragmentation and all technological parameters of milling. The type of formed chips (ergo chip ignition) is determined by, e.g. cutting velocity, the depth of cut or the type (chemical composition) of magnesium alloy [1]. Chip morphology and shape play an equally important role, along with their mass (of both leading and intermediate fractions) $[8,9]$, ignition initiation analysis and partial melting on the surface of $\mathrm{Mg}$ alloys $[2,6,18]$. Magnesium alloys have distinct morphology, on the one hand, they are of lamellar plate structure, on the other hand, their surface is smooth and shiny [4].

Technological considerations designate surface quality (expressed by surface roughness parameters) and cutting forces (affecting the dimensional and shape accuracy) as interesting indices of machinability $[10,16,17,19]$. The analysis of cutting forces during milling with tools of varying cutting edge geometry shows that lower force values and amplitudes were observed at rake angle $\gamma=30^{\circ}[5]$. Moreover, the increase of cutting forces results in deformed chip thickness, hence the increase of temperature in the cutting plane $[3,12,13]$.

\section{METHODOLOGY}

The present study was conducted to analyse the impact of changing $a_{p}$ and rake angle on the number of intermediate fractions of chips. Figure 1 shows the plan for tests conducted with tools of varying cutting edge geometry. The primary objective of the study was to determine technological parameters which would guarantee safety conditions of milling process. The process itself was performed on a vertical machining centre, Avia VMC800HS. The following cutting conditions were accepted: width of engagement $a_{e}=$ $14 \mathrm{~mm}$, cutting velocity $v_{c}=800 \mathrm{~m} / \mathrm{min}$, varying rake angle $\gamma=(5 \div 30)^{\circ}$, and the technological parameters of milling: $a_{p}=(0.5 \div 3) \mathrm{mm}$, at $f_{z}=0.05$ $\mathrm{mm} /$ tooth and $f_{z}=0.15 \mathrm{~mm} /$ tooth. The tests were carried out on AZ91HP magnesium cast alloy.

The description of chips formed in milling tests necessitated the introduction of the following terms:

- fraction - a population of elements of a particular size or dimensions,

- fragmentation - during machining, formation of an intermediate chip fraction of different shape and mass, alongside the leading fraction (prevailing and characteristic).

The division into the leading (main) and intermediate fractions was based on the shape and size of chips, fraction A being the biggest, fraction $\mathrm{D}$ the smallest chips. The term 'leading fraction' was ascribed to fraction A, and smaller fractions were referred to as 'intermediate fractions'. The reference for the chip fraction division was derived from the Polish Norm PN-ISO 3685 1996, which was, however, a classification referring to turning steel.

\section{RESULTS}

Table 1 shows the correlation between $a_{p}$ at $f_{z}=0.05 \mathrm{~mm} /$ tooth and the number of recorded chip fractions and their shape. The highest number of fractions was observed at the lowest depth

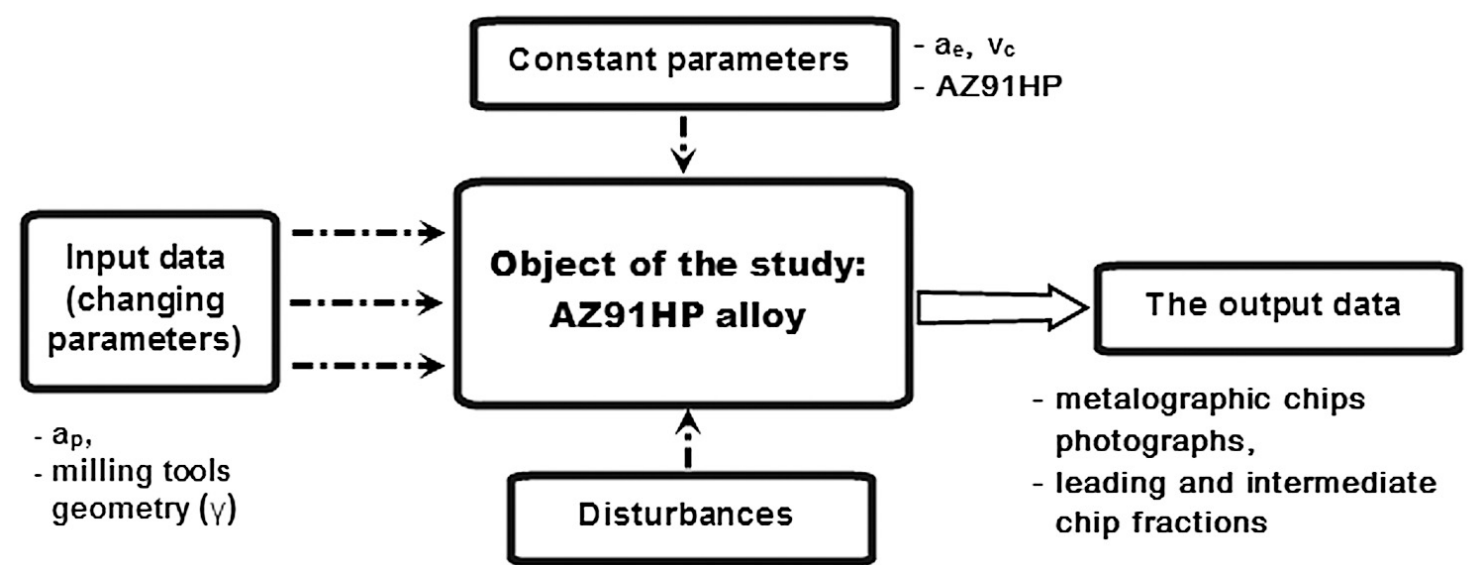

Fig. 1. Test plan for assessment of $a_{p}$ and $\gamma$ impact on chip form 
of cut, fraction A was recognised as washer-type helical, fraction B washer-type helical short, fraction C elemental and D - dust. Fractions A and B obtained at $a_{p}=1.5 \mathrm{~mm}$ are described as tubular compressed because their width is higher than in the case of chips formed at $a_{p}=0.5 \mathrm{~mm}$. Fraction $\mathrm{C}$ was described as elemental. At the depth of cut $a_{p}=3 \mathrm{~mm}$ the shape of chips in the recognised fractions was tubular compressed short (fractions $\mathrm{A}$ and B). Noted differences between fractions concerned chip dimensions. Chips found in fraction $\mathrm{C}$ are recognised as elemental.
Table 1 presents the correlation between the cutting speed and the shape of formed chips and the number of fractions separated in milling at the rake angle of $\gamma=5^{\circ}$. Figure 2 shows examples of chip shapes observed in milling at the change of depth of cut (feed $f_{z}=0.05 \mathrm{~mm} /$ tooth).

Figure 2 shows a selection of fractions determined at the depth of cut of $a_{p}=0.5 \mathrm{~mm}$ and the biggest fraction at $a_{p}=1.5 \mathrm{~mm}$. Fraction D chips (Fig. 2a) are classified as dust, due to their small width and delicate structure, contributing to their easy braking. According to size, the second small-

Table 1. Impact of depth of cut $\mathrm{a}_{\mathrm{p}}$ on chip shape and number of fractions (AZ91HP magnesium cast alloy): a) $a_{p}=$ $\left.0.5 \mathrm{~mm}, \mathrm{~b}) a_{p}=1.5 \mathrm{~mm}, \mathrm{c}\right) a_{p}=3 \mathrm{~mm}$, at $v_{c}=800 \mathrm{~m} / \mathrm{min}, f_{z}=0.05 \mathrm{~mm} /$ tooth and $\gamma=5^{\circ}$

\begin{tabular}{|c|c|c|c|c|c|}
\hline $\begin{array}{l}\text { Fraction } \\
\text { Parameter }\end{array}$ & All fractions & $\begin{array}{l}\text { Leading } \\
\text { fraction A }\end{array}$ & $\begin{array}{c}\text { Intermediate } \\
\text { fraction B }\end{array}$ & $\begin{array}{c}\text { Intermediate } \\
\text { fraction C }\end{array}$ & $\begin{array}{c}\text { Intermediate } \\
\text { fraction } D \\
\end{array}$ \\
\hline $\begin{array}{l}\text { a) } a_{p}=0.5 \mathrm{~mm} \\
f_{z}=0.05 \mathrm{~mm} / \mathrm{tooth}\end{array}$ & & & . & $\infty$ & \\
\hline $\begin{array}{l}\text { b) } a_{p}=1.5 \mathrm{~mm} \\
f_{z}=0.05 \mathrm{~mm} / \text { tooth }\end{array}$ & & & & t) & $\begin{array}{l}\text { no fraction } \\
\text { detected }\end{array}$ \\
\hline $\begin{array}{l}\text { c) } a_{p}=3 \mathrm{~mm} \\
f_{z}=0.05 \mathrm{~mm} / \text { tooth }\end{array}$ & & & & 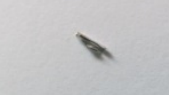 & $\begin{array}{l}\text { no fraction } \\
\text { detected }\end{array}$ \\
\hline
\end{tabular}
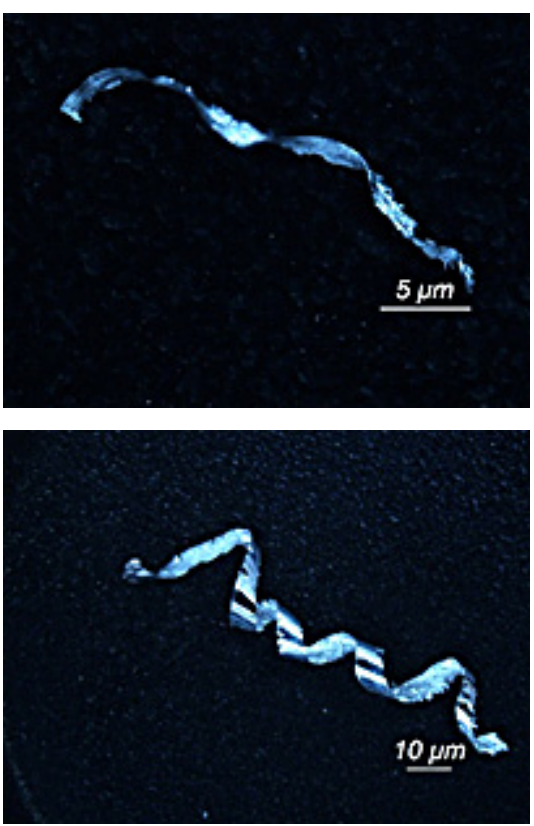
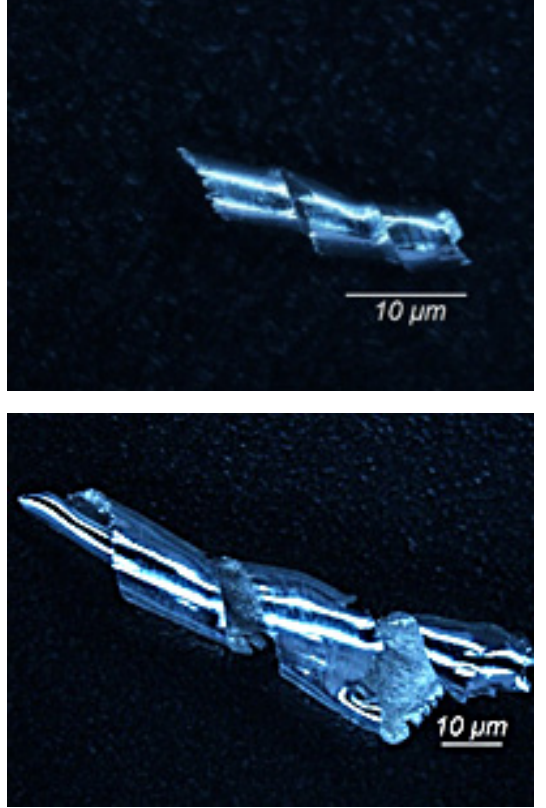

Fig. 2. Chips formed in AZ91HP magnesium cast alloy milling for selected chip fractions and depths of cut $a_{p}$ $\left(f_{z}=0.05 \mathrm{~mm} /\right.$ tooth): a) $a_{p}=0.5 \mathrm{~mm}$, fraction D, b) $a_{p}=0.5 \mathrm{~mm}$, fraction C, c) $a_{p}=0.5 \mathrm{~mm}$, fraction A,

d) $a_{p}=1.5 \mathrm{~mm}$, fraction A 
est fraction was C (Fig. 2b), which consisted of very fine chips of a tightly wound helix. Fraction A was represented by the longest, helical chips of smooth external surface and lamellar internal surface. The most noticeable difference between the leading fractions at $a_{p}=0.5 \mathrm{~mm}$ (Fig. 2c) and $a_{p}=1.5 \mathrm{~mm}$ (Fig. 2d) is the width of chips. Chips formed at the tested milling parameters are less convenient in terms of storage or transport, as due to their coiled shape they require more storage space.

Table 2 shows chip fractions formed with a changed depth of cut $a_{p}$ at the feed rate $f_{z}=0.15$ $\mathrm{mm} /$ tooth. Table 2 indicates that when the depth of cut was the lowest, 3 chip fractions were formed. Due to their small size chips in fraction $\mathrm{C}$ are considered as dust, and chips belonging to fractions A and B as washer-type helical. Chips of fraction $B$ are notably shorter than those of fraction $\mathrm{A}$, therefore could be regarded as elemental chips, however, their shape resembles the washertype helical type. Fractions A and B contain tubular compressed chips at the depth of cut $a_{p}=1.5$ $\mathrm{mm}$. Fraction $\mathrm{C}$ includes arc chips, whereas fraction D, elemental. At the depth of cut $a_{p}=3 \mathrm{~mm}$ tubular compressed chips were formed (fraction $\mathrm{A}$ and $\mathrm{B}$ ) and loose arc chips (fraction C and D). It ought to be mentioned that fraction A chips are significantly longer than in fraction $\mathrm{B}$, and chips of fraction $\mathrm{D}$ are more coiled than chips representing fraction $\mathrm{C}$.

Figure 3 presents chips classified as the smallest and the biggest fractions at different depths of cut. At the depth of cut $a_{p}=0.5 \mathrm{~mm}$ fraction A (Fig. 3a) contained the longest chips, similarly to fraction A at $a_{p}=3 \mathrm{~mm}$ (Fig. $3 \mathrm{c}$ ). Considerable differences were observed not only in terms of width but the tightness of the helix as well. Fraction A chips at $a_{p}=0.5 \mathrm{~mm}$ had a tighter helix and their structure was quite uniform, whereas the leading fraction at the depth of cut of $3 \mathrm{~mm}$ had a notably less uniform chip, with distinct bends and cuts on the edges. Chips belonging to fraction $\mathrm{C}$ at the depth of cut $a_{p}=0.5 \mathrm{~mm}$ were distinctly different from other chips in terms of size and shape. These were small elements of highly frayed edges, very well seen in magnified picture. At the depth $a_{p}=$ $0.5 \mathrm{~mm}$ three fractions were determined. Fractions A and B were classified as washer-type helical, however, fraction A chips were over three times as long as chips of fraction $\mathrm{B}$ and $\mathrm{C}$, the latter were classified as dust. At the depth of cut of $a_{p}=1.5 \mathrm{~mm}$ fractions $\mathrm{A}$ and $\mathrm{B}$ were determined as tubular compressed, and chips of fraction $\mathrm{C}$ as elemental. Both fractions formed at $a_{p}=3 \mathrm{~mm}$ were classified as tubular compressed.

Table 3 presents the impact of cutting velocity on the shape of formed chips and the number of fractions obtained in milling conducted at the tool rake angle $\gamma=30^{\circ}$. The analysis of table 3 indicates that the change of the depth of cut $a_{p}$, at $f_{z}=0.05 \mathrm{~mm} /$ tooth, does impact the shape of chips and the degree of their fragmentation. Figure 4 shows chip shapes formed during milling of AZ91HP magnesium alloy with a changed depth of cut $a_{p}$ at the feed rate $f_{z}=0.05 \mathrm{~mm} /$ tooth.

Table 2. Impact of depth of cut $\mathrm{a}_{\mathrm{p}}$ on chip shape and number of fractions (AZ91HP magnesium cast alloy): a) $a_{p}=$ $\left.0.5 \mathrm{~mm}, \mathrm{~b}) a_{p}=1.5 \mathrm{~mm}, \mathrm{c}\right) a_{p}=3 \mathrm{~mm}$, at $v_{c}=800 \mathrm{~m} / \mathrm{min}, f_{\mathrm{z}}=0.15 \mathrm{~mm} /$ tooth and $\gamma=5^{\circ}$

\begin{tabular}{|c|c|c|c|c|c|}
\hline \begin{tabular}{|l} 
Fraction \\
Parameter
\end{tabular} & All fractions & $\begin{array}{l}\text { Leading } \\
\text { fraction } \mathrm{A}\end{array}$ & $\begin{array}{l}\text { Intermediate } \\
\text { fraction B }\end{array}$ & $\begin{array}{l}\text { Intermediate } \\
\text { fraction C }\end{array}$ & $\begin{array}{c}\text { Intermediate } \\
\text { fraction D }\end{array}$ \\
\hline $\begin{array}{l}\text { a) } a_{p}=0.5 \mathrm{~mm} \\
f_{z}=0.15 \mathrm{~mm} / \text { tooth }\end{array}$ & है & & 8 & $c$ & $\begin{array}{l}\text { no fraction } \\
\text { detected }\end{array}$ \\
\hline $\begin{array}{l}\text { b) } a_{p}=1.5 \mathrm{~mm} \\
f_{z}=0.15 \mathrm{~mm} / \text { tooth }\end{array}$ & & & 7 & 8 & 4 \\
\hline $\begin{array}{l}\text { c) } a_{p}=3 \mathrm{~mm} \\
f_{z}=0.15 \mathrm{~mm} / \text { tooth }\end{array}$ & & & & 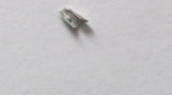 & 8 \\
\hline
\end{tabular}



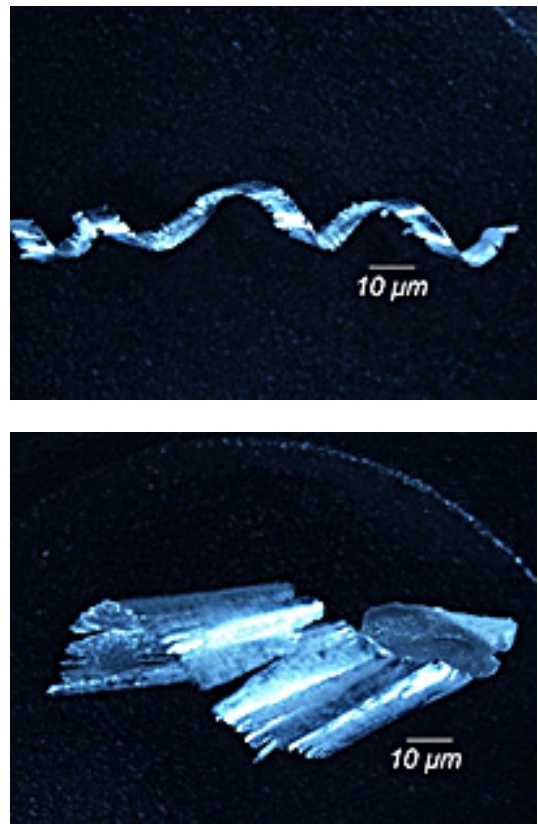
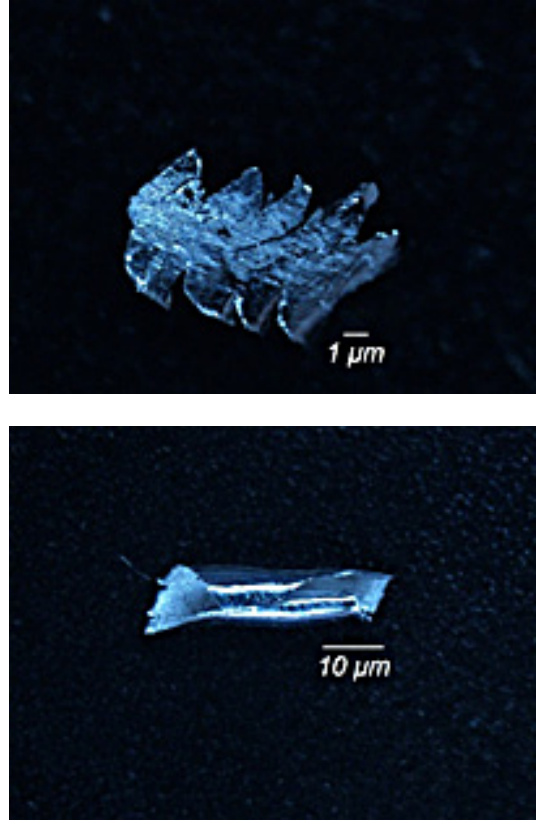

Fig. 3. Chips formed in AZ91HP magnesium cast alloy milling for selected chip fractions and depths of cut $a_{p}\left(f_{z}=0.15 \mathrm{~mm} /\right.$ tooth $):$ a) $a_{p}=0.5 \mathrm{~mm}$, fraction A, b) $a_{p}=0.5 \mathrm{~mm}$, fraction C, c) $a_{p}=3 \mathrm{~mm}$, fraction A, d) $a_{p}=3 \mathrm{~mm}$, fraction $\mathrm{D}$

Chips of fraction C (Fig. 4b) were of small size and therefore classified as dust. Fraction A (Fig. 4a) consisted of long coiled chips, which due to their shape could be difficult in transport and storing. The outer surface of chips formed at the highest depth of cut was shiny and deformations were visible only at the edges. The tightness of the helix at $\gamma=30^{\circ}$ was higher than in the case of $\gamma=5^{\circ}$, which is most clearly visible in the leading fraction of the depth of cut $a_{p}=3 \mathrm{~mm}$.
Table 4 presents chip photographs illustrating the correlation between the depth of cut $a_{p}$ (at $f_{z}=0.15 \mathrm{~mm} /$ tooth) and the shape and number of fractions classified. It can be observed that the highest number of fractions was observed at the depth of cut $a_{p}=1.5 \mathrm{~mm}$, while at the other depths there were 3 fractions. When the depth of cut was the lowest, fractions A and B (washer-type helical chips) and $C$ (dust) were distinguished. The width of chip increased with the increase of the depth of

Table 3. Impact of depth of cut $\mathrm{a}_{\mathrm{p}}$ on chip shape and number of fractions (AZ91HP magnesium cast alloy): a) $a_{p}=$ $0.5 \mathrm{~mm}$, b) $a_{p}=1.5 \mathrm{~mm}$, c) $a_{p}=3 \mathrm{~mm}$, at $v_{c}=800 \mathrm{~m} / \mathrm{min}, f_{z}=0.05 \mathrm{~mm} /$ tooth and $\gamma=30^{\circ}$

\begin{tabular}{|c|c|c|c|c|c|}
\hline \begin{tabular}{|l} 
Fraction \\
Parameter \\
\end{tabular} & All fractions & $\begin{array}{l}\text { Leading } \\
\text { fraction A }\end{array}$ & $\begin{array}{l}\text { Intermediate } \\
\text { fraction B }\end{array}$ & $\begin{array}{l}\text { Intermediate } \\
\text { fraction C }\end{array}$ & $\begin{array}{c}\text { Intermediate } \\
\text { fraction D }\end{array}$ \\
\hline $\begin{array}{l}\text { a) } a_{p}=0.5 \mathrm{~mm} \\
f_{z}=0.05 \mathrm{~mm} / \text { tooth }\end{array}$ & $\cdots$ & & 5 & * & $\begin{array}{l}\text { no fraction } \\
\text { detected }\end{array}$ \\
\hline $\begin{array}{l}\text { b) } a_{p}=1.5 \mathrm{~mm} \\
f_{z}=0.05 \mathrm{~mm} / \text { tooth }\end{array}$ & $\frac{1}{1}=$ & & $\infty$ & 1 & $\begin{array}{l}\text { no fraction } \\
\text { detected }\end{array}$ \\
\hline $\begin{array}{l}\text { c) } a_{p}=3 \mathrm{~mm} \\
f_{z}=0.05 \mathrm{~mm} / \text { tooth }\end{array}$ & & & & $\begin{array}{l}\text { no fraction } \\
\text { detected }\end{array}$ & $\begin{array}{l}\text { no fraction } \\
\text { detected }\end{array}$ \\
\hline
\end{tabular}



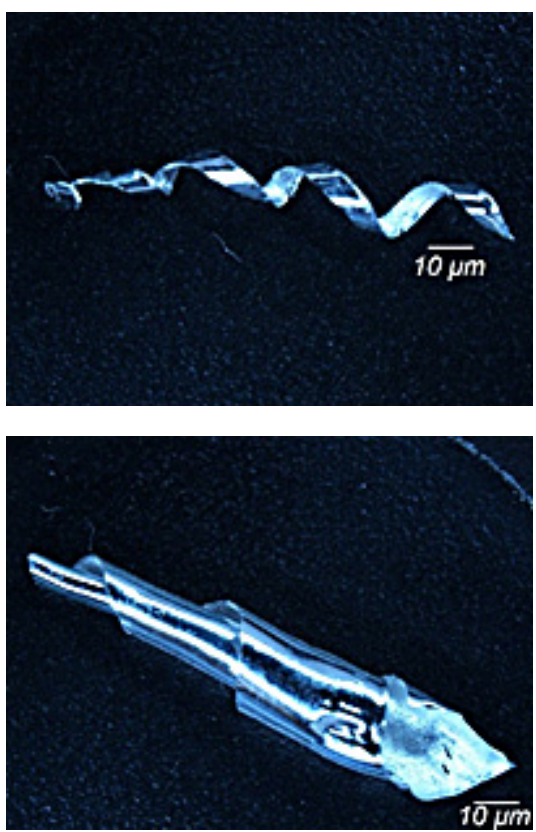
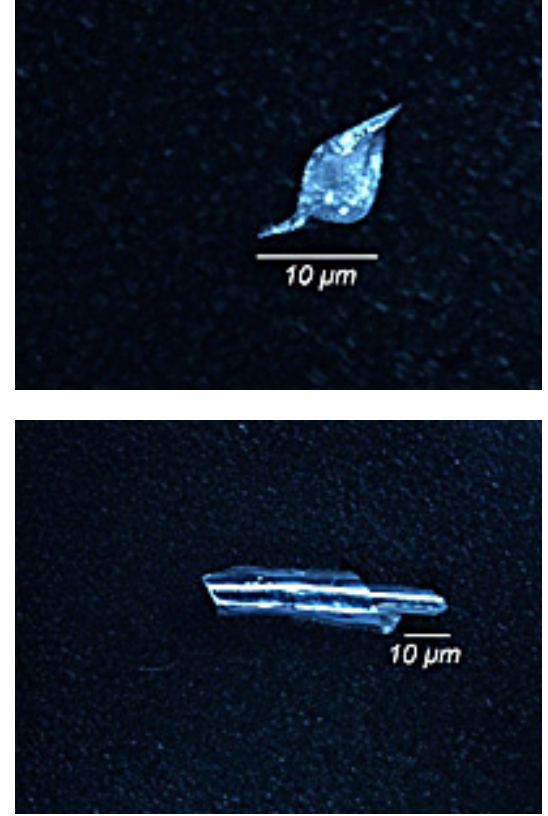

Fig. 4. Chips formed in AZ91HP magnesium cast alloy milling for selected chip fractions and depths of cut $a_{p}\left(f_{z}=0.05 \mathrm{~mm} /\right.$ tooth $):$ a) $a_{p}=0.5 \mathrm{~mm}$, fraction A, b) $a_{p}=0.5 \mathrm{~mm}$, fraction C, c) $a_{p}=3 \mathrm{~mm}$, fraction A, d) $a_{p}=3 \mathrm{~mm}$, fraction $\mathrm{B}$

cut, therefore, fractions A and B $\left(a_{p}=1.5 \mathrm{~mm}\right)$ were recognised as tubular compressed chips. Fraction D represented dust and fraction $\mathrm{C}$ contained elemental chips. At the depth of cut $a_{p}=3 \mathrm{~mm}$ the formed chips were of tubular compressed shape. Figure 5 shows chip shapes formed during AZ91HP magnesium alloy milling, performed with a changed depth of cut $a_{p}$ at the feed rate $f_{z}=0.15 \mathrm{~mm} /$ tooth.

Figure 5 shows the smallest fractions distinguished at the depths of cut $a_{p}=0.5 \mathrm{~mm}, a_{p}=$
$1.5 \mathrm{~mm}$ and $a_{p}=3 \mathrm{~mm}$. In the case of $a_{p}=0.5$ $\mathrm{mm}$ and $a_{p}=1.5 \mathrm{~mm}$ the smallest fractions represented small chips of tight helical shape and smooth edges, classified as dust. While the length of chips was roughly similar for fractions $\mathrm{C}$ and $\mathrm{D}$ $\left(a_{p}=1.5 \mathrm{~mm}\right)$, the main difference concerned the shape and size of chips, which could be described as arc. Chips of fraction $\mathrm{C}\left(a_{p}=3 \mathrm{~mm}\right)$ had a characteristically tighter helix in comparison to other smallest chip fractions.

Table 4. Impact of depth of cut $\mathrm{a}_{\mathrm{p}}$ on chip shape and number of fractions (AZ91HP magnesium cast alloy): a) $a_{p}=$ $\left.0.5 \mathrm{~mm}, \mathrm{~b}) a_{p}=1.5 \mathrm{~mm}, \mathrm{c}\right) a_{p}=3 \mathrm{~mm}$, at $v_{c}=800 \mathrm{~m} / \mathrm{min}, f_{z}=0.15 \mathrm{~mm} /$ tooth and $\gamma=30^{\circ}$

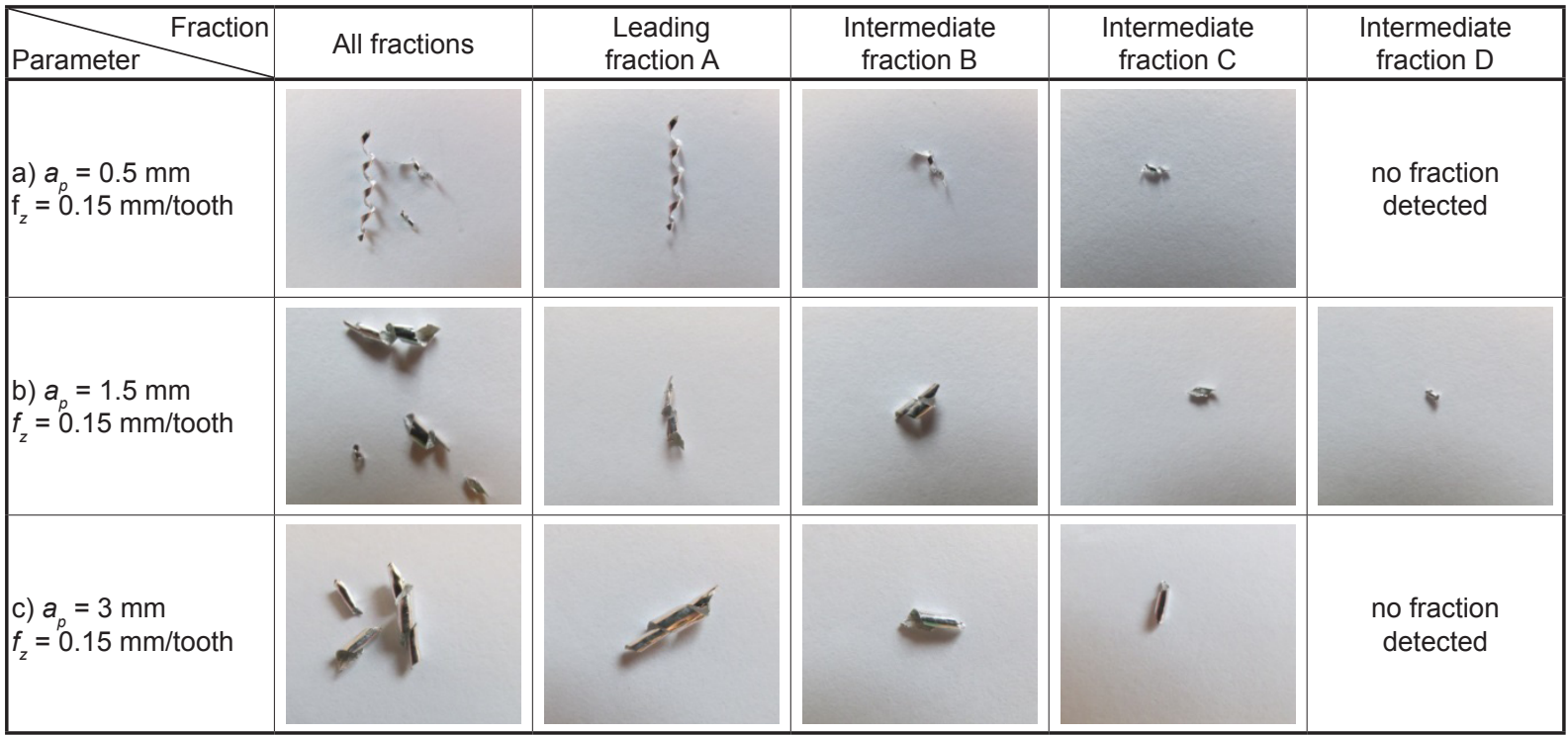



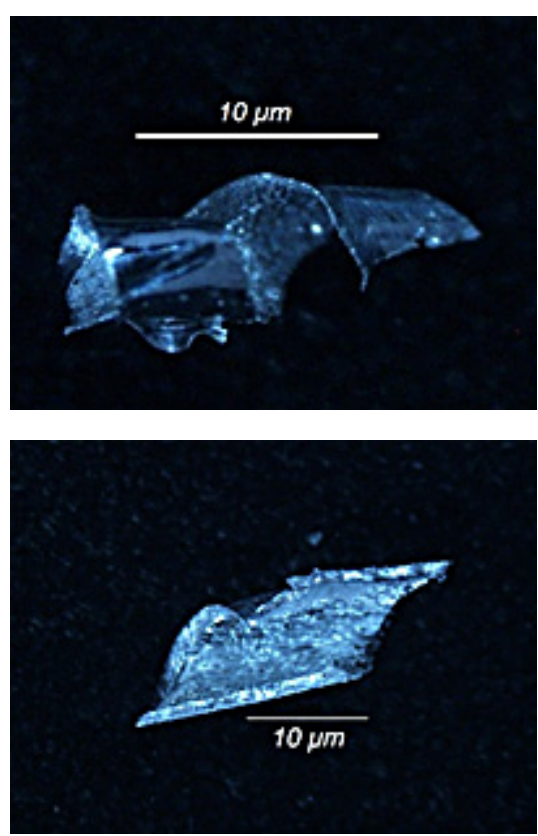
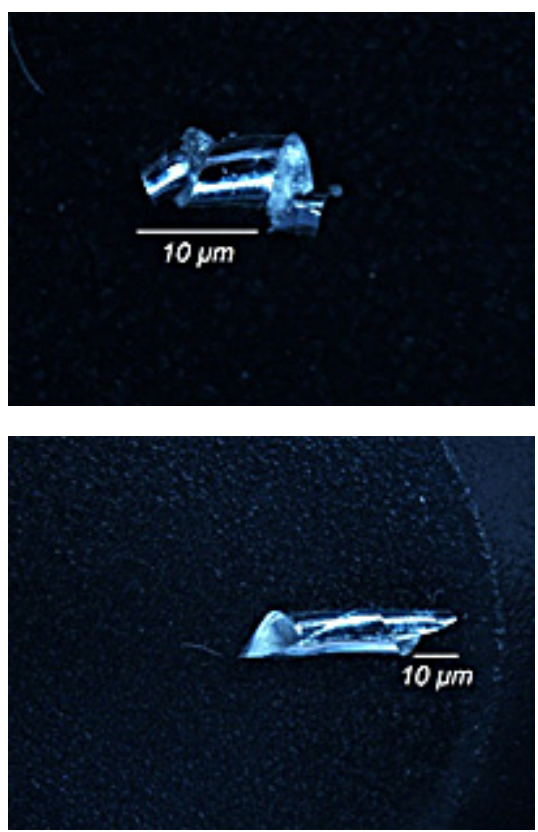

Fig. 5. Chips formed in AZ91HP magnesium cast alloy milling for selected chip fractions and depths of cut $a_{p}\left(f_{z}=0.15 \mathrm{~mm} /\right.$ tooth $):$ a) $a_{p}=0.5 \mathrm{~mm}$, fraction C, b) $a_{p}=1.5 \mathrm{~mm}$, fraction $\mathrm{D}$, c) $a_{p}=1.5 \mathrm{~mm}$, fraction C, d) $a_{p}=3 \mathrm{~mm}$, fraction $\mathrm{C}$

\section{CONCLUSIONS}

The conducted study points at the type of changes regarding technological parameters of milling (mainly $a_{p}$ ). The tests conducted within the analysed area of variables focused on the depth of cut $a_{p}$. The tests assessed the impact of both the depth of cut $a_{p}$ and the rake angle of the tool $\gamma$ on the number of chip fractions formed in $\mathrm{Mg}$ alloy milling. The presented study may serve as an indicator of parameters for effective and safe AZ91HP magnesium alloy milling.

A potentially hazardous area, accepting the formation of a visible dust fraction as a criterion of safety, is when the depth of cut was the lowest: $a_{p}=0.5 \mathrm{~mm}$ and $a_{p}=1.5 \mathrm{~mm}$. These parameters contributed to increased levels of dust fraction formation in milling. Moreover, other chips formed in these conditions were either washertype helical or tubular compressed, which makes their transport and storage highly inconvenient.

The presented results clearly show that the fewest chip fractions were formed at the tool rake angle $\gamma=30^{\circ}$. It appears that the parameter which is specifically responsible for the number of formed chip fractions is the depth of cut $a_{p}$. Moreover, at the lowest depth of cut the highest amount of dust fractions was observed: intermediate fraction $\mathrm{D}\left(a_{p}\right.$ $=0.5 \mathrm{~mm}, f_{z}=0.05 \mathrm{~mm} /$ tooth, $\left.\gamma=5^{\circ}\right)$, intermediate fraction $\mathrm{C}\left(a_{p}=0.5 \mathrm{~mm}, f_{z}=0.15 \mathrm{~mm} /\right.$ tooth, $\gamma=$ $\left.5^{\circ}\right)$, intermediate fraction $\mathrm{C}\left(a_{p}=0.5 \mathrm{~mm}, f_{z}=0.05\right.$ $\mathrm{mm} /$ tooth, $\left.\gamma=30^{\circ}\right)$, intermediate fraction $\mathrm{C}\left(\mathbf{a}_{\mathbf{p}}=\right.$ $0.5 \mathrm{~mm}, f_{z}=0.15 \mathrm{~mm} /$ tooth,$\left.\gamma=30^{\circ}\right)$ and intermediate fraction $\mathrm{D}\left(a_{p}=1.5 \mathrm{~mm}, f_{z}=0.15 \mathrm{~mm} /\right.$ tooth, $\gamma=30^{\circ}$ ). The form of chip obtained in the depths of cut between $0.5 \div 3 \mathrm{~mm}$ is undesired, as its thin and coiled shape is unfavourable in terms of chip evacuation, transport and storage.

The conclusions drawn from the results of the study are as follows:

1. Fewer fractions, hence a lesser degree of chip fragmentation, are formed at the tool rake angle $\gamma=30^{\circ}$.

2. The largest number of fractions was obtained with the change of the depth of cut $a_{p}$ (when compared with conducted as a part of this study, however not described in this analysis, other technological parameters).

3. A hazardous area with regards to dust fraction formation is at the lowest depths of cut: $a_{p}=$ $0.5 \mathrm{~mm}$ and $\mathrm{a}_{\mathrm{p}}=1.5 \mathrm{~mm}$.

4. The most advantageous chips, easily evacuated from the milling machine's workspace and not requiring additional storage space, are formed when the depth of cut is equal or higher than $a_{p}=3 \mathrm{~mm}$.

5. The present study concludes that AZ91HP magnesium alloy should be conducted at considerably high values of $a_{p}$ and 'sharp' tool geometry. 


\section{Acknowledgements}

Financial support of Structural Funds in the Operational Programme - Innovative Economy (IE OP) financed from the European Regional Development Fund, Nr POIG.01.01.02-00-015/0800 is gratefully acknowledged.

\section{REFERENCES}

1. Akyuz B.: Machinability of magnesium and its alloys. The Online Journal of Science and Technology, 1(3), 2011, 31-38.

2. Arai M., Sato S., Ogawa M., Shikata H.I.: Chip control in finish cutting of magnesium alloy. Journal of Materials Processing Technology 62, 1996, 341-344.

3. Fang F.Z., Lee L.C., Liu X.D.: Mean flank temperature measurement in high speed dry cutting, Journal of Materials Processing Technology, 167, 2005, 119-123.

4. Guo Y.B., Salahshoor M.: Process mechanics and surface integrity by high-speed dry milling of biodegradable magnesium-calcium implant alloys. CIRP Annals - Manufacturing Technology, 59, 2010, 151-154.

5. Gziut O., Kuczmaszewski J., Zagórski I.: The influence of technological parameters and geometric features of a cutting edge on cutting forces during AZ91HP alloy milling. Advances in Manufacturing Science and Technology, 38(2), 2014, 83-92.

6. Hou J.Z., Zhou W., Zhao N.: Methods for prevention of ignition during machining of magnesium alloys. Key Engineering Materials, Vol. 447-448, 2010, 150-154.

7. Kuczmaszewski J.: Efektywność wytwarzania elementów lotniczych ze stopów aluminium i magnezu. Komputerowo Zintegrowane Zarządzanie, Oficyna Wyd. Polskiego Towarzystwa Zarządzania Produkcją, Opole 2011, 7-18.

8. Kuczmaszewski J., Zagórski I.: Badania fragmentowania wiórów w procesie frezowania stopów magnezu (in Polish). Mechanik, Vol. 8-9, 2014, 321-328.

9. Kuczmaszewski J., Zagórski I.: Control of the weight, ignition temperature and actual tempera- ture of chips produced when machining some selected magnesium alloy grade (in Polish). Mechanik, Vol. 10, 2012, 824-828.

10. Kuczmaszewski J., Zagórski I.: The study of cutting forces and amplitudes during the milling magnesium alloys (in Polish). Advances in Science and Technology Research Journal, Vol. 15, 2012, 228-237.

11. Le Coz G., Marinescu M., Devillez A., Dudzinski D., Velnom L.: Measuring temperature of rotating cutting tools: Application to MQL drilling and dry milling of aerospace alloys. Applied Thermal Engineering, Vol. 36, 2012, 434-441.

12. Li, H.Z., Liu, K., Li, X.P.: A new method for determining the undeformed chip thickness in milling.Journal of Materials Processing Technology, 113(1-3), 2001, 378-384.

13. Lotfi Sai, Bouzid W., Zghal A.: Chip thickness analysis for different tool motions for adaptive feed rate. Journal of Materials Processing Technology, 204(1-3), 2008, 213-220.

14. Oczoś K.E.: Extension of the magnesium alloys application range (in Polish), Mechanik, Vol. 5-6, 2009, 386-400.

15. Oczoś K.E., Kawalec A.: Light metals forming (in Polish). PWN, Warsaw 2012.

16. Zagórski I., Kuczmaszewski J.: The study of cutting forces and their amplitudes during high-speed dry milling magnesium alloys. Advances in Science and Technology Research Journal, 7(20), 2013, 61-66.

17. Zagórski I., Pieśko P.: Badania porównawcze chropowatości powierzchni wybranych stopów magnezu po frezowaniu narzędziem pełno-węglikowym oraz PKD. Postępy Nauki i Techniki, No. 8, 2011, 53-58.

18. Zhao N., Hou J., Zhu S.: Chip ignition in research on high-speed face milling AM50A magnesium alloy. Second International Conference on Mechanic Automation and Control Engineering, 15-17 July 2011, Inner Mongolia, China.

19. http://www.nanomag.us/Hydro_Mg_Brochure Machining_Mg.pdf Machining magnesium, z dnia 19.01.2012.

20. Polska Norma: Badanie trwałości noży tokarskich punktowych, PN-ISO 3685:1996.

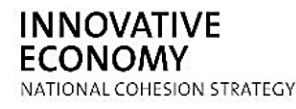

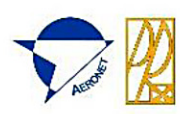

EUROPEAN UNION DEROPEAN REGIONAL

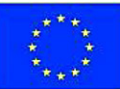

